\title{
A Study on the Effective Path of Dance Education at Colleges and Universities from the Perspective of Ecology
}

\author{
Ruizhi Zhang \\ School of Arts \& International Education, Hunan City University, Yiyang, 413000, China \\ Email: 13622746@qq.com
}

\begin{abstract}
In recent years, the theory of ecological outlook has been applied to the study of various disciplines and has become a new way of innovation and development in various disciplines. The study of dance education in colleges and universities from the perspective of ecological outlook is of great significance. This paper explores the significance of ecological concept and ecological theory to college dance education as well as the effective path of college dance education.
\end{abstract}

Keywords: Ecological outlook, dance teaching, path

\section{Introduction}

With the continuous development of society, the concept of "ecological environment" has received more and more attention, and ecological civilization has become a new paradigm of current social development. Integrating ecological concepts into dance education is an important way to innovate and develop dance education [1].

\section{Definition of Relevant Concepts}

The concept of ecological outlook: Ecology is the science that studies the relationship between biology and the environment [2]. The environment he refers to includes the non-biological environment and the biological environment. This is the definition of "ecology" by German zoologists in the book "Principles of General Morphology of Organisms" in 1866. Ecological outlook is a human-based philosophy that is based on ecology and reflects on the philosophical worldview of human beings, nature, society and so on. Today, in China, the promotion of quality education, dance education as an important component of cultural education, the introduction of ecological and diversified educational concepts into teaching has important practical significance for the development of its subject education.

The concept of effective teaching: from the perspective of ecological outlook, the teaching process is a teaching ecosystem involving multiple factors [3]. In such an organic whole, various factors communicate with each other, and the interaction adjusts the relationship of disharmony and imbalance to a harmonious and balanced relationship, and finally achieves the established teaching effect. This is the effective teaching under ecological outlook. The factors involved in the effective teaching process include teachers, teaching environment, students, etc., and various factors restrict and influence each other in order to achieve the teaching effect that the overall function is greater than the sum of some functions.

\section{Significance of the Ecological Outlook Theory for Dance Education at Colleges and Universities}

At present, the current situation of dance education at colleges and universities in China is basically a college-style teaching mode that emphasizes dance knowledge and skills. It ignores the fact that dance education is a characteristic of education. The introduction of the theory of ecological outlook overcomes the negative influence of current dance education, truly understands and constructs the meaning of dance education from the perspective of human beings, and improves the deficiencies of dance education that is too utilitarian and neglects humanistic education [4]. 
First of all, the dance classroom is a kind of ecosystem that requires the participation of teachers and students, students and students, teaching objectives and teaching processes. To achieve effective teaching, it is necessary balance the relationship between various factors, so that students can fully develop their body and mind in the process of receiving dance education; Secondly, the relationship between man and dance is also an ecosystem that needs to be balanced, and it must reflect the subjective position of people in dance teaching. Paying attention to the value people get in dance can maximize the meaning of the dance classroom and promote the sustainable development of dance education; Finally, the creation of dance comes from life, and the survival and continuation of dance cannot be separated from the ecosystem in which the social background and cultural background exist. Thus, the overall environment is critical to the development of dance. College dance education with the introduction of ecological outlook theory can adapt to the needs of people's all-round development, in order to truly realize dance education.

\section{Characteristics in the Design of College Dance Education from the Perspective of Ecological Outlook}

For the ecological outlook to be introduced into college dance education, it is necessary not only to continuously improve the educational theory, but also to follow the basic principles and requirements of ecological outlook in the curriculum design.

First of all, the interactive nature of the course. In the past, dance education was mainly based on imparting knowledge. However, dance education under ecological outlook pays more attention to the interaction between teachers and students. It regards the participants of the dance teaching activities as a whole, pays attention to the interaction between the various parts, and promotes them through deep mutual communication.

Secondly, the college dance teaching from the perspective of ecological outlook has diversified functions. With the continuous development of dance education, learners are not only satisfied with learning knowledge and skills, but also pursue the improvement of humanistic quality and achieve their own comprehensive development. With the introduction of ecological outlook, various factors work together in the teaching process, which makes dance education can stimulate students' subjective initiative, participate in teaching, and better understand the essence and connotation of dance.

Thirdly, dance education tends to be more integrated with life. Dance education should be organically linked to the daily dance life of students. Individual dance learning should be carried out along with the dance activities in daily life, integrating dance into the overall environment of daily life culture, and the overall way of perception makes students more acceptable. The dance education combined with daily life will also connect people with nature and society in a kind of integrated thinking and feelings and integrate the meaning of life in the process of guiding students' skill learning in dance. These are all important at the current stage. Today's society is an information society, and the arrival of the Internet affects people's lives. Students not only receive dance education at dance classes but also experience dance and accept dance through various channels. In such a social environment, dance education should not simply limit students to textbooks and classrooms. Teachers should have an open attitude, walk out of the classroom, and enter students' real life and social activities, so that the dance content is more life-like, which makes it easier for students to understand and accept their learned knowledge.

\section{Analysis of Effective Path for College Dance Educations}

\subsection{Follow the Basic Principle of Ecological Outlook and Establish the Classroom Ecology}

The construction of classroom ecology is mainly reflected in the processing of teacher-student relationship in dance education. The ecological outlook negates the teacher' imparting of knowledge and the student passively accepting knowledge; it advocates the interaction between teachers and students and believes that it is the incompetence and complementarity of the two sides that constitute the basis and premise of the classroom ecological values. The process of education and teaching is more about the interdependence of teachers and students, the process of mutual penetration, complementarity and common development in value. Educators should not over-pursue the utilitarian aspects of education, should be based on the 
intrinsic value of individual self-realization, respect individual differences and personal dignity. In addition, teachers should also pay attention to the integrity of the classroom ecology. The factors in the classroom ecology are interdependent and mutually influential. Coordinating the relationship between them can make the overall function more than the sum of the functions of each part. In order to eliminate negative influences, students should be motivated to a great extent, each individual's subject status should be respected, and their individual needs should be met. At the same time, we must have a developmental thinking mode and respond to the changing factors in a timely manner. Only by grasping the dynamic characteristics of the dance teaching classroom and balancing the interests of all parties in a timely manner can we ensure effective teaching, improve teaching quality, and promote students' all-round development.

\subsection{Diversified Contents of Dance Education}

Diversification is also an attribute of ecological outlook, which is characterized by diversity in teaching content. The textbook contains not only Chinese excellent dance works but also foreign works, both national and world, both popular and classical. In the setting of dance teaching content in colleges and universities, all aspects should be balanced, presenting students with rich and colorful dance genres and enriching students' dance experience.

\subsection{Transfer the Dance Education Mode}

It is necessary to change the dance teaching mode and understand dance teaching from the perspective of ecological concept. In the process of dance teaching, we should first recognize that dance belongs to creation, and it needs a cognitive background environment in the process of learning. Learners should also gradually transform this cognition from being rational to being sensible and integrate wisdom and experience. The form of dance teaching in its natural form does not have the school system and standardized learning content in the traditional teaching method. The mastery of the learning and skills of dance knowledge is gradually becoming more and more proficient in an atmosphere. From this comprehensive atmosphere, the overall charm of the dance itself is constantly displayed, and the dance is perceived as a whole in this form. Therefore, college dance education under the perspective of ecological outlook emphasizes the initiative to develop a variety of new teaching models, not limited to the single mode of classroom teaching. Teachers can call on students to learn independently, to learn classroom knowledge flexibly, to interact with teachers and students in the classroom, to enhance students' musical quality, not just dance knowledge and skills, thus promoting students' overall development.

Acknowledgement. This research was supported by the following funding:

1. General scientific research project of hunan provincial department of education: research on multicultural landscape of hunan city dance, hunan provincial department of education, Xiangjiaotong [2016] 239 (16C0317).

2. Research project on teaching reform of hunan city university in 2018: theoretical construction and practical exploration of curriculum system of dance performance major in application-oriented undergraduate colleges, (no. 1 of Xiangcheng university [2018]).

\section{References}

1. Long Huifang. Dance Education from the Perspective of Ecological Outlook [J]. Northern Dance, 2016,36(07):204.

2. Shi Alice, Deng Hongyan, Xu Yifang. Research on Effective Classroom Teaching in Colleges and Universities from the Perspective of Educational Ecology [J]. Asia Pacific Education, 2015(16):293+278.

3. He Ling, Xia Wei. Research on Preschool Education Professional Dance Education from the Perspective of Ecological Outlook [J]. Journal of Hubei Correspondence University, 2018,31(07):144-145.

4. Cao Yang. Research on the Development of College Dance Education Based on the Perspective of Ecological Outlook [J]. Contemporary Teaching and Research, 2018(09):20. 